\title{
Image, Memory, and Allusion in the Textual History of the Apocalypse: GA 2028 and Visual Exegesis ${ }^{1}$
}

\author{
GARRICK V. ALLEN ${ }^{2}$
}

The book of Revelation is vexed by a complex textual history, a reality wrought by the relative paucity of substantive papyri and other early manuscripts, as well as the tradition's preservation of a divided byzantine text (the Andrew of Caesarea tradition and the Koine family of texts). ${ }^{3}$ In scholarly discourse, the texts of Revelation's manuscripts have rightly been privileged as the resource of primary value for criticism. This value that is cashed out, so to speak, in the worth of the text's ability to contribute to the creation of the initial text, or in the textual peculiarities of a given manuscript that provide evidence for the theological understanding of scribal tradents ${ }^{4}$ or their practices of transcription. ${ }^{5}$ But manuscripts are more than the texts they carry, and are artefacutually valuable even if they carry an unremarkable text. Apart from the concerns of textual criticism

1 I wish to express my gratitude to Christian Förstel, conservateur chargé des manuscrits grecs at the Bibliothèque national de France, for his assistance in arranging a consultation with the manuscript, and to the Deutsche Forschungsgemeinschaft for generously funding this consultation.

2 The author is a research associate of the School of Ancient Languages, University of Pretoria.

3 For more on the issues associated with Revelation's textual history see: Josef Schmid, Studien zur Geschichte des griechischen Apokalypse-Textes (MThS.HE 1), 3 vols., München 1955 1956; Markus Lembke, Beobachtungen zu den Handchriften der Apokalypse des Johannes, in: M. Karrer/M. Labahn (eds.), Die Johannesoffenbarung. Ihr Text und ihre Auslegung (ABG 38), Leipzig 2012, 19-69; Martin Karrer, Der Text der Johannesapokalypse, in: J. Frey/J.A. Kelhoffer/F. Tóth (eds.), Die Johannesapokalypse: Kontexte-Konzepte-Rezeption (WUNT 287) Tübingen 2012, 43-78; Tobias Nicklas, The Early Text of Revelation, in: C. E. Hill/M. J. Krueger (eds.), The Early Text of the New Testament, Oxford 2012, 225-238; J. K. Elliott, New Testament Textual Criticism: The Application of Thoroughgoing Principles: Essays on Manuscripts and Textual Variation (NTSup 137), Leiden 2010, 145-155; Juan Hernández Jr., Scribal Tendencies in the Apocalypse: Starting the Conversation, in: C. A. Evans/H. D. Zacharias (eds.), Jewish and Christian Scripture as Artifact and Canon (LSTS 70), London 2009, $248-250$

4 E.g. Bart D. Ehrman, The Orthodox Corruption of Scripture: The Effect of Early Christological Controversies on the Text of the New Testament, Oxford 1993 and Juan Hernández Jr., Scribal Habits and Theological Influences in the Apocalypse (WUNT 2/218), Tübingen 2006.

5 E.g. James R. Royse, Scribal Habits in Early Greek New Testament Papyri (NTTSD 36), Leiden 2008. 
and text-genetic stemmatics, the material culture of manuscripts (i.e. manuscripts as artefacts) and the ways that they present and frame their texts provides another, largely overlooked, channel of tradition for examining the reception of a work in a given period. Physical features of manuscripts provide evidence for how scribes and readers comprehended and interpreted the text they copied, ${ }^{6}$ including text segmentation, use of nomina sacra, paratexts, and divisions between commentary and scriptural text, among others. What follows in this article is an attempt to explore how a particular feature of a single manuscript's bibliographic code illuminates its artist's perception of the text (i.e. the linguistic code). How does a socio-historically contextualised manuscript illuminate how the text it transmits was understood by its producers?

The word "illuminate" is appropriate in this context, since manuscript GA 2028 (BN Gr. 239; Hoskier 62) is the earliest exemplar of a miniature cycle of four images that appear in fifteenth and sixteenth century copies of the Andrew of Caesarea commentary of the book of Revelation (cf. 20442054 2083). Although the illumination in this manuscript is muted in comparison to examples from the richly colourful Carolingian Latin tradition of Revelation (see below) or more ornate miniatures in other Greek NT manuscripts (especially the Gospels), 2028 presents a useful example for examining the artistic reception of Revelation's Greek text for numerous reasons. ${ }^{7}$ First, the quasi-legible colophon by a second hand on $117 \mathrm{v}$ dates the manuscript's completion to 9 October 1422 $\mathrm{CE}$ and attributes its production to the scribe "Michael[?] Kalophrena a priest and sinner." A dated manuscript allows us to place its artistic representations within a particular historical context. ${ }^{9}$ Moreover, although the artistic representations are relatively subtle in comparison to the cycles of images associated with Revelation's medieval Latin traditions, the illustrations in 2028, consisting of zoomorphic initial letters at the beginning of new Andreas kephalaia and the previously mentioned mini-cycle of Revelation's cosmic antagonists, offer a window into how the formal shape and layout of a text controls or contributes to its meaning. The following discussion focuses not primarily on the text of

6 Or at least how the text was understood in a given textual milieu. Of course the primary scribe did not make every interpretive decision, nor is every physical characteristic of a manuscript a function of interpretation.

7 The artistic contents of the manuscript were first described, as far as I am able to ascertain, by H. Bordier, Description des peintures et autres ornements contenus dans les manuscrits grecs de la Bibliothèque Nationale, Paris 1883, 265.

8 Cf. H. C. Hoskier, Concerning the Text of the Apocalypse, 2 vols., London 1929, 1.197.

9 For an overview of patterns of illuminations in manuscripts of this period, see I. Spatharakis, Corpus of Dated Illuminated Greek Manuscripts to the Year 1453, vol. 1, Leiden 1981. Generally, very few Greek manuscripts of this period contain images of the Apocalypse. The most ubiquitous image is that of John with Prochoros (e.g. Patmos MS. 81, 238v), but this is usually connected to the Gospel of John. 
2028 , but on the ways that the artwork embedded in the manuscript provides evidence for how the book of Revelation was interpreted by this particular artist. Do the images in this manuscript constitute interpretive endeavours, and if so, what traditional precursors influenced that artist? First, it is important to briefly describe the physical characteristics of the manuscript and its process of production.

\section{Codicology}

2028 contains the book of Revelation accompanied by the Andreas of Caesarea commentary, written in a single column on the recto and verso of 117 bound leaves. The binding of the book appears to be original, but is in relatively poor condition. The final two leaves of the codex $(118 v-119 v)$ contain a faded work written by a later hand that Hoskier titled "a fragment concerning the infancy of the Saviour."10 The manuscript is written on paper with dimensions of approximately $21 \mathrm{x} 14 \mathrm{~cm}$; it is a professional copy, keeping a largely consistent number of lines (between 27 and 29) and consistent margins even though there is no clear evidence of ruling.

The manuscript also exhibits signs of an involved process of production. The four images associated with the cycle (see below) were created before the copying of text on these pages, as the copyist writes over parts of the images, while avoiding this when possible. However, the colourful zoomorphic capitals are clearly secondary to the copying process, since they themselves make up part of the text. Additionally, the production of text and paratexts of the manuscripts (produce by the same scribe) was a layered event. It seems that the main text was copied first in black ink and then corrected in the process of producing the Andreas apparatus (red ink). ${ }^{11}$ That the colophon is in red ink indicates that the red ink used in the manuscript is of a secondary layer. The workflow of this collaborative project appears to have function in this manner: 1) artist (cycle of images); 2) scribe (inscription of text [black ink]; 3) scribe (inscription of paratexts, capitals, and corrections [red ink]); 4) artist (zoomorphic capitals). ${ }^{12}$

10 Hoskier, Concerning, 1.197. The text on the final two folia of 2028 is a form of the so-called Infancy Gospel of Thomas. J. Noret, Pour une edition de l'Évangelie de l'Enface selon Thomas, Analecta Bollandiana 90 (1972), 412 identifies BN gr. 239 as one of the manuscripts that was to be collated in a new edition of this work.

11 The only correction that arose during the first stage of production occurs at $17.17(81 \mathrm{v})$.

12 This division of labour is not unlike other manuscripts of the era produced in a number of context. Cf. e.g. BnF, fr. 12577, commented upon by Keith Busby, Text and Image in the Getty Tristan, Los Angeles, J. Paul Getty Museum, MS Ludwig, 5, in: H. A. Kelly (ed.), Medieval 
The commentary segments and scriptural text are visibly distinguished throughout by the use of marginal abbreviations ( $\varepsilon \rho \mu$ and $\kappa \varepsilon \imath)$, diplés, and capitals (all in red ink), although there is some confusion, particularly when the commentary cites a remote portion of the main text. For example, the quotation of Rev 17.18 in the commentary on $17.1-3$ is paratextually marked as main text, even though it is clearly part of the comment. This leads to a situation where two slightly different forms of 17.18 are preserved as scriptural text in this exemplar. ${ }^{13}$ The base text is also repeated before and after a commentary segment in places (e.g. 11.18; 17.9). The Andrew kephalaia and logoi are marked consistently throughout the manuscript, but are often embedded in the preceding commentary section $2-6$ lines before the section it marks. There are few corrections in the manuscript (e.g. $4.3[19 \mathrm{v}] ; 14.20[65 \mathrm{r}] ; 16.16[73 \mathrm{v}] ; 17.17[81 \mathrm{v}]$ ) and the palaeography, while cursive and ligature-laden, is clear. ${ }^{14}$ Many of the non-zoomorphic capitals are highly stylized.

\section{Artistic Representations}

A distinguishing visual feature of this manuscript is its numerous artistic representations, a feature that is relatively unique in Revelation's Greek tradition. The following table catalogues the instances of artistically rendered capitals in 2028 and the cycle of images associated with Revelation's dragons and beasts. These representations stand close to other late Byzantine illuminations from Greece and Cyprus, suggesting that the tradition originated in this milieu. ${ }^{15}$

Manuscripts, Their Makers and Users, Los Angeles, 2011, 1-25. There exists a complex relationship between artistic and textual affinities based on the ad hoc and informal relationships between scribes and artisans in various location and at various times. See K. Maxwell, The Afterlife of Texts: Decorative Style Manuscripts and New Testament Textual Criticism, in: L. Jones (ed.), Byzantine Images and their Afterlives: Essays in Honor of Annemarie Weyl Carr, Farnham, 2014, 11-38. This is also true in particular monastic settings in the west in this period. Cf. J. T. McQuillen, Fifteenth-Century Book Networks: Scribes, Illuminators, Binders, and the Introduction of Print, PBSA 104 no 4 (2013), 495-515.

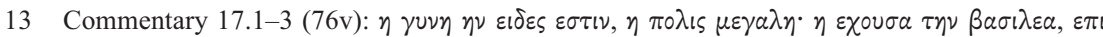

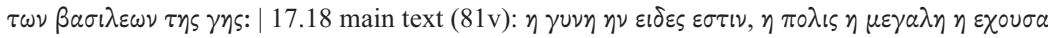

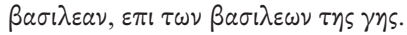

14 The style coheres loosely to V. Gardthausen's "mittelere Minuskel" (Die Schrift, Unterschriften und Chronologie im Altertum und im byzantinischen Mittelater, vol. 2, Leipzig 1913, 217.

15 For example, see the image in Codex 590 from the Vatopedi Monastery on Mount Athos (29v) on Job 9. 
Table 1: Illustrations in 2028

\begin{tabular}{|c|c|c|c|c|}
\hline Folio & Text & Kephalaia $^{16}$ & $\begin{array}{l}\text { Initial Cap- } \\
\text { ital? }\end{array}$ & Description \\
\hline $1 \mathrm{r}$ & $\begin{array}{l}\text { Table of } \\
\text { Contents }\end{array}$ & $\mathrm{N} / \mathrm{A}$ & N/A & $\begin{array}{l}\text { A green lion sitting upon the illumi- } \\
\text { nated gold header intertwined with } \\
\text { vine-like foliage above the extended } \\
\text { title. }\end{array}$ \\
\hline $3 r$ & Prologue & N/A & Yes & $\begin{array}{l}\text { A brown rabbit whose legs are being } \\
\text { devoured by two dark green beasts. } \\
\text { Together they create the initial } \pi \text { in } \\
\pi \mathrm{o} \lambda \lambda \alpha \kappa ı \varsigma \text {. }\end{array}$ \\
\hline $4 v$ & 1.1 & $\mathrm{~A}^{*}$ & Yes & $\begin{array}{l}\text { Beneath the illuminated header, a bird } \\
\text { and a lion are intertwined to create the } \\
\mathrm{A} \text { in } \mathrm{A} \pi \mathrm{\alpha} \alpha \alpha \lambda v \psi \mathrm{c} \text {. }\end{array}$ \\
\hline $36 v$ & 8.7 & KB* & Yes & $\begin{array}{l}\text { The } \kappa \text { in the initial K } \alpha \text { of the scrip- } \\
\text { tural text is a six-line-tall lion wearing } \\
\text { a crown and attached to two small } \\
\text { birds, seated on their tail feathers, that } \\
\text { make up the legs of the } \kappa \text {. }\end{array}$ \\
\hline $41 \mathrm{v}$ & 9.13 & $\mathrm{KZ}^{*}$ & Yes & $\begin{array}{l}\text { The } \kappa \text { in the initial Kol of the scrip- } \\
\text { tural text is a nine-line-tall lion hold- } \\
\text { ing a bird to make up the diagonal up- } \\
\text { ward stoke and a beast attempting to } \\
\text { eat a hare is the downward diagonal } \\
\text { stroke. }\end{array}$ \\
\hline $46 v$ & 11.3 & $\Lambda^{*}$ & Yes & Identical image to $36 \mathrm{v}$ \\
\hline $49 \mathrm{r}$ & 11.15 & $\Lambda \mathrm{B}^{*}$ & Yes & $\begin{array}{l}\text { The } \kappa \text { in the initial Kal of the scrip- } \\
\text { tural text is a seven-line-tall winged } \\
\text { beast with spots, holding a smaller } \\
\text { bird in its talons. }\end{array}$ \\
\hline $51 \mathrm{r}$ & 12.3 & $\Lambda \Gamma$ & No & $\begin{array}{l}\text { The bottom margin of the page and } \\
\text { lower right margin contain an image } \\
\text { of the serpentine creature described in } \\
12.3 \text {. It is crimson red, wearing gold } \\
\text { crowns. The dragon also drags stars } \\
\text { from heaven (12.4). }\end{array}$ \\
\hline $53 r$ & 12.7 & $\Lambda \Delta^{*}$ & Yes & $\begin{array}{l}\text { The } \kappa \text { in } \kappa \alpha \mathrm{t} \text { is a red, stylized three-di- } \\
\text { mensional capital that appears to be a } \\
\text { crowned, hollow candlestick. }\end{array}$ \\
\hline $54 \mathrm{v}$ & 12.13 & $\Lambda \mathrm{E}^{*}$ & Yes & $\begin{array}{l}\text { The last line of this leaf is a combina- } \\
\text { tion of animals in the shape of a } \kappa: \text { a } \\
\text { green-winged lion that has another } \\
\text { lion head facing backward in its abdo- } \\
\text { men. }\end{array}$ \\
\hline
\end{tabular}

$16 *$ indicates that the illustration inaugurates a new kephalaia. 


\begin{tabular}{|c|c|c|c|c|}
\hline Folio & Text & Kephalaia $^{16}$ & $\begin{array}{l}\text { Initial Cap- } \\
\text { ital? }\end{array}$ & Description \\
\hline $56 \mathrm{r}$ & 13.1 & $\Lambda \mathrm{S}$ & No & $\begin{array}{l}\text { The bottom right margin contains a } \\
\text { large illustration of the creature de- } \\
\text { scribed in } 13.1-2 \text {. It is serpentine, but } \\
\text { has the appearance of a leopard, the } \\
\text { feet of a bear and the head of a lion, } \\
\text { having also seven heads and ten } \\
\text { horns. It is wearing red and green } \\
\text { crowns. }\end{array}$ \\
\hline $58 \mathrm{r}$ & 13.11 & $\Lambda Z$ & No & $\begin{array}{l}\text { The bottom margin contains an illus- } \\
\text { tration of the land beast described in } \\
\text { 13.11. It is a large coiled snake with } \\
\text { two lamb's horns that is dark green } \\
\text { with red spots. }\end{array}$ \\
\hline $61 \mathrm{v}$ & 14.6 & $\mathrm{M}^{*}$ & Yes & Same image as $36 \mathrm{v}$ and $46 \mathrm{v}$. \\
\hline $71 \mathrm{r}$ & 16.10 & $\mathrm{~N}^{*}$ & Yes & Same candlestick $\kappa$ as $53 \mathrm{r}$. \\
\hline $72 v$ & 16.12 & NA* & Yes & $\begin{array}{l}\text { An eight-line-tall light-green bird } \\
\text { perched on its tail feathers with a re- } \\
\text { gal plume constitutes the } \kappa \text { that begins } \\
\text { the kephalaion. }\end{array}$ \\
\hline $74 v$ & 16.17 & NB* & Yes & $\begin{array}{l}\text { The } \kappa \text { that begins this kephalaion is } \\
\text { made up of a vertical rabbit ( } 8 \text { lines } \\
\text { tall) who is being attacked by two } \\
\text { birds that create the arms of the } \\
\text { grapheme. They have drawn blood. }\end{array}$ \\
\hline $76 \mathrm{r}$ & 17.1 & $\mathrm{~N} \Gamma^{*}$ & Yes & Same as 36v, 46v, 61v. \\
\hline $76 \mathrm{r}$ & $17.1-3$ & $\mathrm{~N} \Gamma$ & No & $\begin{array}{l}\text { In the lower right margin, the whore } \\
\text { of Babylon is seated up a scarlet, } \\
\text { seven-headed, ten-horned beast. She } \\
\text { is dressed extravagantly in a red gar- } \\
\text { ment with gold spots and holds a gold } \\
\text { cup in her right hand. The beast is } \\
\text { once again similar to the previous il- } \\
\text { lustrations. }{ }^{17}\end{array}$ \\
\hline $78 \mathrm{r}$ & $17.6-7$ & $\mathrm{~N} \Delta^{*}$ & Yes & Same image as $72 \mathrm{v}$ \\
\hline $89 v$ & 19.11 & $\mathrm{NH}^{*}$ & Yes & $\begin{array}{l}\text { The image constitutes } \kappa \text { and includes } \\
\text { four faces: a human face in profile, a } \\
\text { lion, and two other creatures. }\end{array}$ \\
\hline
\end{tabular}

A close inspection of the manuscript reveals two interlocking, but distinct patterns of illumination. First, in addition to a number of less stylized capitals that are deployed consistently to distinguish between commentary and scriptural text, there are fifteen examples of highly imaginative capitals that are usually

17 Spatharakis, Corpus, describes the creature riding the beast as an angel, but this is clearly wrong. 
comprised of combinations of various animals. ${ }^{18}$ The lion of the illuminated header (1r) is related to this larger pattern, particularly in the four instances where a crowned lion is used to make the initial kappa of $\kappa \alpha 1$, in combination with two birds seated on stumps $(36 \mathrm{v}, 46 \mathrm{v}, 61 \mathrm{v}, 76 \mathrm{r})$.

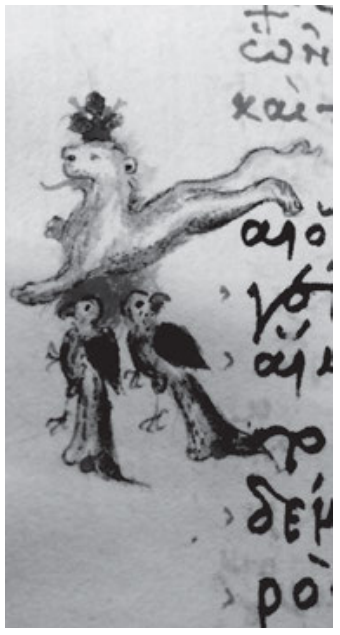

$36 \mathrm{v}$

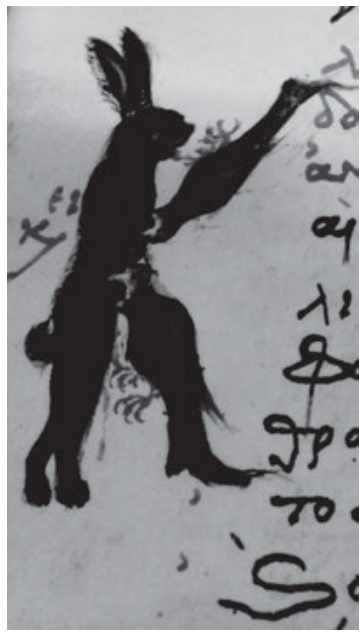

$74 \mathrm{v}$

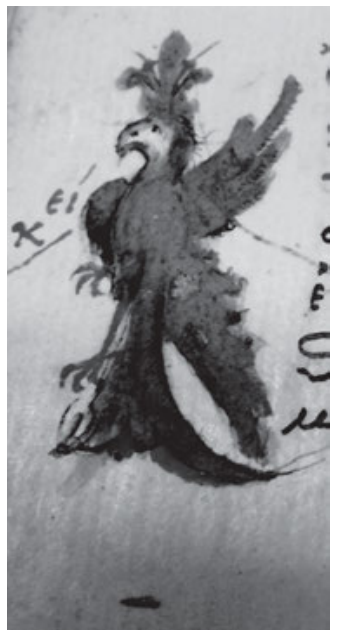

$72 v^{19}$

This series of artistic representations of Greek letters each correspond to the beginning of a new Andrew kephalion connected to the scriptural text, indicating that the formal shape of the commentary tradition influenced the deployment of these images. However, the choice of animal in each image does not necessarily correspond to the meaning of the surrounding text. For example, the use of a perched bird $(72 \mathrm{v})$ does not seem to relate to any of the commentary or scriptural text in the area. Two possible exceptions exist for this pattern. The large hare at the beginning of Rev $16.17(74 \mathrm{v})$ may perhaps symbolise the ruddiness of the Whore who appears in the next chapter, and the fact that the birds are eating the hare prefigures her downfall and the fate of the armies defeated in 19.21. Likewise, the stylized capital at Rev 19.11 seems to be connected to the text.

18 Cf. also similar examples of this phenomenon in other Byzantine manuscripts, e.g. Dionysiou Cod. 150 from Mt. Athos (plates in S. M. Pelekanidis et al. (eds.), The Treasures of Mount Athos: Illuminated Manuscripts, 2 vols., Athens 1974, 1.134-136, 426-427.

19 Photos by author. 


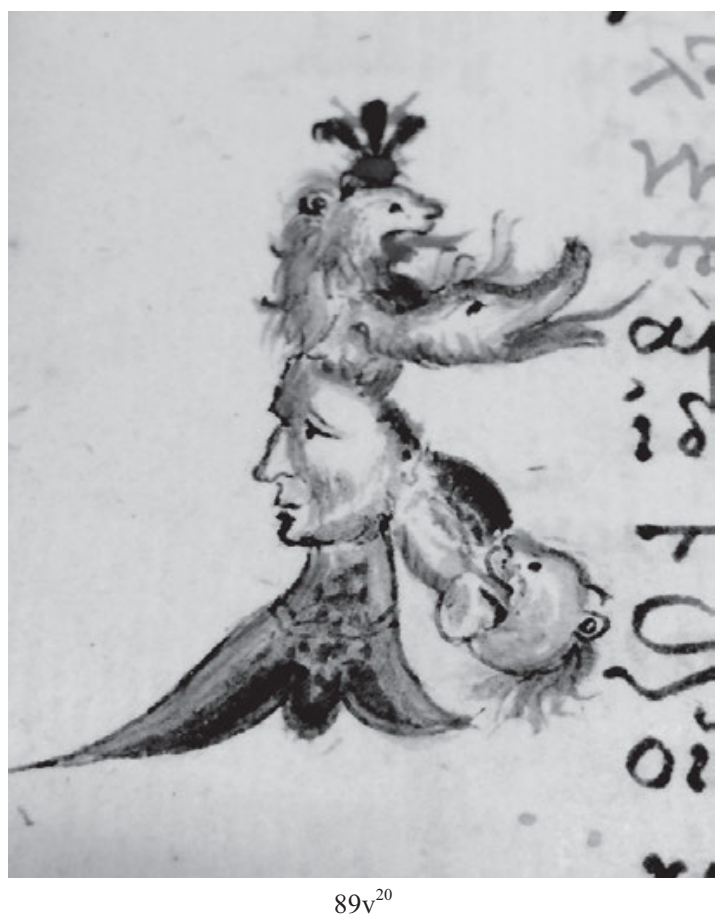

This image is unique among the stylized capitals in 2028 and is the only that depicts a human. It is well established that Rev 19.11 alludes to Ezekiel 1 (cf. Rev 4.6-7), ${ }^{21}$ and it is this connection that explains the deployment of this image here. Each of the four winged beings that Ezekiel beholds in 1.5-14 are described as having four faces: one like a human, another like a lion, a third like a calf, and a fourth like an eagle. The image on $89 \mathrm{v}$ combines the faces described in Ezekiel into the shape of a kappa, even mimicking the straight legs ( $\tau \dot{\alpha} \sigma \kappa \varepsilon \dot{\lambda} \eta \eta$

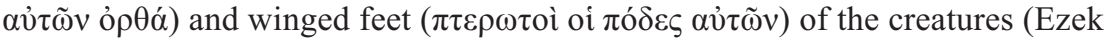
1.7). The face of the lion and the human are quite obvious, while the faces that comprise upper diagonal stroke of the kappa (eagle?) and the lower diagonal stroke (calf?) are not as discernible. Nonetheless, the connection between Ezekiel 1 and this image is suggestive. In this case it seems that artistic representa-

20 Photo by author.

21 So G. K. Beale, The Book of Revelation (NIGTC), Grand Rapids 1999, 949; Pierre Prigent, L’Apocalypse de Saint Jean, rev. ed., Geneva 2000, 415; Beate Kowalski, Die Rezeption des Propheten Ezechiel in der Offenbarung des Johannes (SBB 52), Stuttgart 2004, 208-210, among others. 
tions of Greek letters may constitute a further avenue of measuring "Old Testament awareness" in NT manuscripts. ${ }^{22}$ The creatures that make up the Greek capital visually allude to a text that is already alluded to in the text of Rev 19.11, even if the correspondence between the visualisation in 2028 and the description in Ezekiel are not identical. The image creates a supplementary layer of allusion to the text to which it is connected.

Interestingly, the Andreas commentary is ambivalent to the allusion to Ezekiel, noting only that "Heaven opening signifies the appearance of the visible judge to come, just as here, when the curtains of the judges on the earth are drawn back, the judgement and sentence come down when guilty, ${ }^{, 23}$ an implicit acknowledgment of a tradition of heavenly disclosure. It seems that the artist drew from some other resource beyond the commentary in the process of crafting this image. This resource may be the text itself. Regardless of the image's antecedent, the capital letter functions as an intertextual mediator, connecting Rev 19.11 to an underlying textual tradition associated to the scene. The artist works within the form of the commentary to accomplish this goal, inserting the image at the start of a new kephalaion, but the final shape of the letter and the tradition it imbibes is ultimately shaped by influences beyond the commentary tradition.

Another parallel stream of illuminations is located in a cycle of four images connected to Rev $12.3 ; 13.1-3,11 ; 17.1-3$, images that are not connected to the substance of the text like the capitals, but which are independent entities. These illuminations portray the four cosmic antagonists of the Apocalypse: the red dragon, the sea beast, the land beast, and the whole of Babylon.

22 See the recent article of Ronald H. van der Bergh, 'Old Testament Awareness' and the Textual Tradition of the Explicit Quotations of Isaiah in Codex Bezae's Acts, NT 57 (2015), 360-378.

23 English quoted from E. S. Constantinou, Andrew of Caesarea: Commentary on the Apocalypse (The Fathers of the Church 123), Washington, D.C. 2011, 200. 


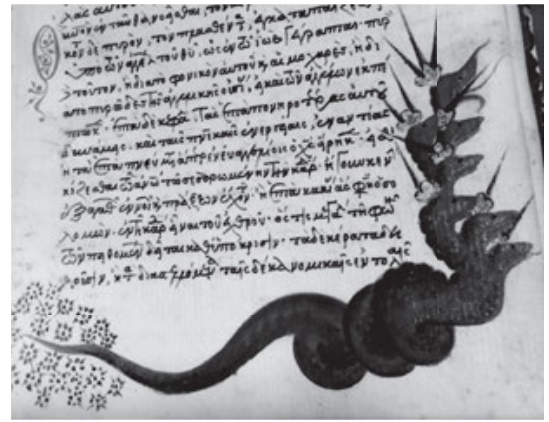

$51 \mathrm{r}^{24}$
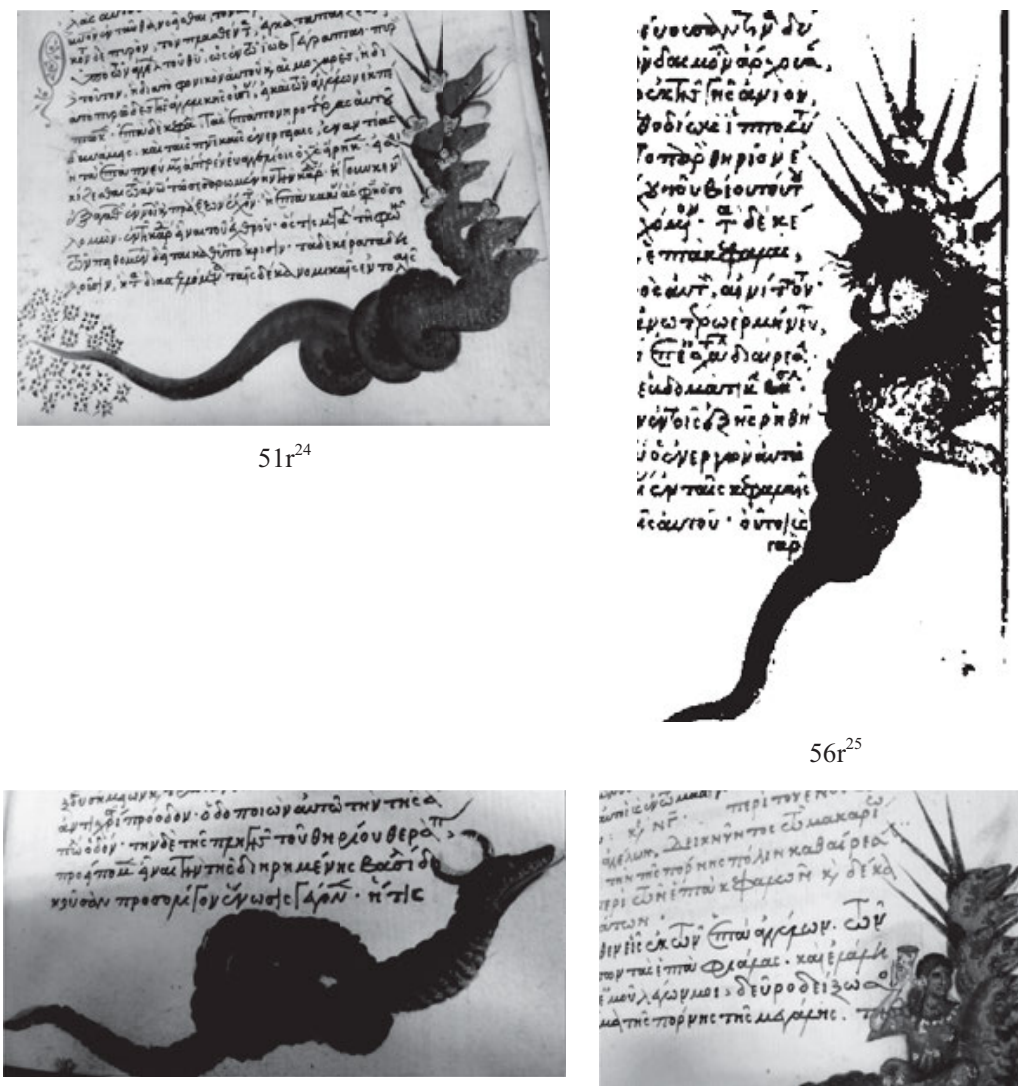

$58 \mathrm{r}$

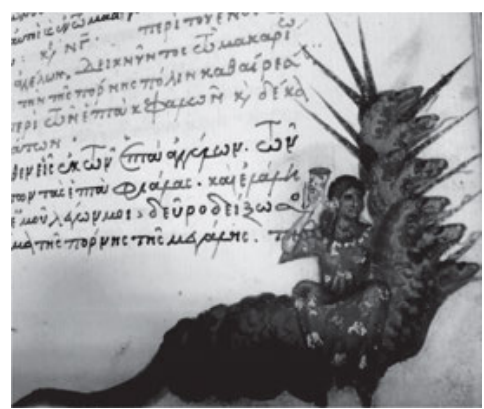

$76 \mathrm{r}$

This cycle of images is of reception-historical interest because features of the images evidence a close reading of the texts that they visualise. The image of the red dragon, for example (51r), not only takes into account the physical description of the "sign in heaven," but also depicts the actions of the dragon's tail which "drags a third of the stars of heaven and casts them to the earth." 51v also contains an extended marginal note that further explains the significance of the

24 Photos expect 56r by author.

25 Excerpt from http://gallica.bnf.fr/ark:/12148/btv1b10722720c/f63.image.r=grec\%20239 (accessed 17 February 2016). 
dragon, text that is incorporated into the commentary in 2044 and located in the margin in 2069, but this description does not influence the form of the dragon. ${ }^{26}$

The image of the sea beast (13.1-2) is also derivative of close attention to the text. Like the textual description, the beast has seven heads and ten horns, a similarity with the dragon from 12.3 that influenced the artist to depict this creature as a serpent, even though this characteristic of the beast is not explicitly articulated. The beast also has spots like leopard, feet like a bear, and a mouth like a lion. Its crowns are connected to each of its horns. In this instance, however, the content of the commentary may have influenced the artist, since Andrew notes that "The ten horns and with the diadems and the seven heads hint at the union of the devil-for these were also explained above as belonging to him. ${ }^{27}$ The serpentine-like character of the beast draws a comparable parallel to the depiction of the dragon, implicitly agreeing with the Andrew commentary that these features of the dragon and sea beast are integrally related. In this way, the image stands in the same traditional stream as the commentary. The representation of the land beast ( $\operatorname{Rev} 13.11$ ) is also graphically related to the preceding images of the sea beast and dragon. It has two lamb's horns as described in the text, but it is depicted as a coiled serpent, even though the text only goes so far as to say that the beast speaks like a dragon. Additionally, the threatening presentation of the beast stands in contrast to Andrew's commentary which argues that the beast has "horns like a lamb, because he completely covers with sheep's skin the hidden murderous character of the wolf., ${ }^{, 2}$ For Andrew, the danger of the land beast is his ability to mislead and appear harmless; the depiction here contrasts this assessment, highlighting the menacing nature of the beast and its direct connection to the dragon. Again, the serpentine characteristics of each of these images suggest that the various creatures are integrally related in the text.

This point is once more emphasised in the depiction of the whore of Babylon seated atop a seven-headed, ten-horned beast, holding a cup in right hand on 76r (cf. Rev 17.1-4). There is no indication in the text that the beast is a serpent,

26 For Greek text cf. Schmid, Apokalypse-Kommentar, 125. Interestingly, text is attached to other images in the manuscript. On 1r, the lion seated atop the illuminated header is bracketed by the words $\bar{\imath} \bar{v} \mu$ ov $\beta o \eta \theta \varepsilon 1 \varepsilon \mu o v$, meaning "my Jesus, my helper" or some similar gloss. This identification suggests that the leonine imagery in the manuscript (esp. the capitals in 36v, 46v, $61 \mathrm{v}, 76 \mathrm{r}$ ) is designed to evoke positive associations with Jesus, "the lion of the tribe of Judah" (Rev 5.5). Another short marginal note directly underneath the first capital in the scriptural text

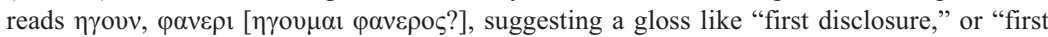
information."

27 Constantinou, Andrew, 147.

28 Constantinou, Andrew, 151. 
but image of this beast is strikingly similar to the representation of the dragon (51r), indicating a strong connection between creatures.

The images in 2028 find parallels in a group of sixteenth century Andrew commentary manuscripts copied by a scribe called Andreas Darmarios (2044 2054 2083). ${ }^{29}$ For example, see the images located in 2044 :

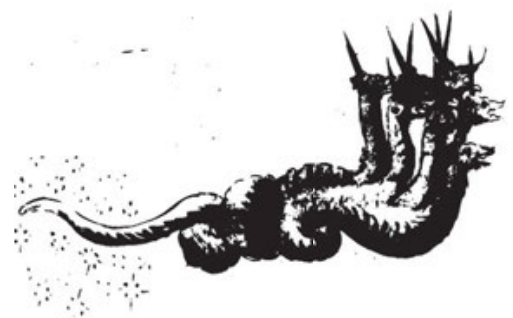

$2044(53 v)^{30}$

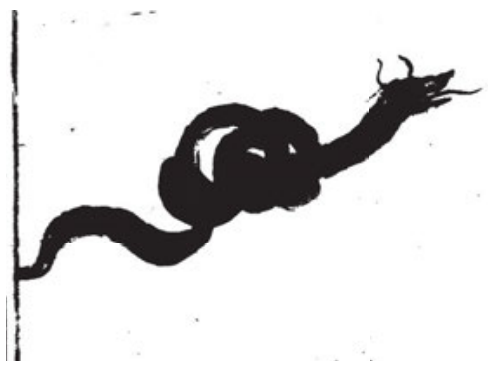

$2044(61 v)^{32}$

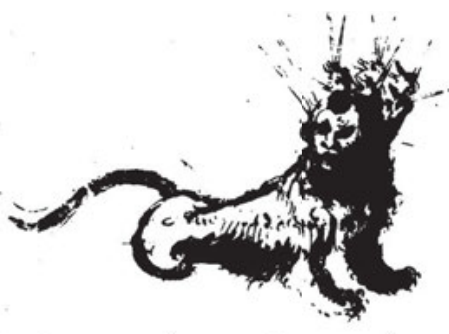

$2044(59 r)^{31}$
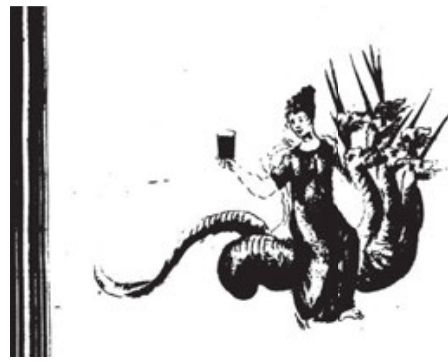

$2044(80 v)^{33}$

The dragon depicted in 12.3 (51r) in 2028 is similar to the serpentine figure with seven heads and ten horns found in 2044 at 12.3 (53v), as the dragon also sweeps

29 Cf. Schmid, Studien, 1.13-15. For more on Darmarios, see O. Kresten, Der Schreiber und Handschrifthändler Andreas Darmarios: Eine biographische Skizze, Mariahilfer Gymnasium Jahresbericht (1967/68), 6-11; H. Hunger, Schreiben and Lesen in Byznanz. Die byzantinische Buchkultur, München 1989, 140.

30 Excerpt from http://ntvmr.uni-muenster.de/community/modules/papyri/?site=INTF\&image= $32044 / 570584 / 1090 / 10 / 434$ (accessed 17 February 2016).

31 Excerpt from http://ntvmr.uni-muenster.de/community/modules/papyri/?site=INTF\&image= 32044/570584/1200/10/844 (accessed 17 February 2016).

32 Excerpt from http://ntvmr.uni-muenster.de/community/modules/papyri/?site=INTF\&image= 32044/570584/1250/10/794 (accessed 17 February 2016).

33 Excerpt from http://ntvmr.uni-muenster.de/community/modules/papyri/?site=INTF\&image= 32044/570584/1630/10/1074 (accessed 17 February 2016). 
the stars from the sky. Additionally, the sea beast in 13.1 in 2044 (59r) is noticeably similar to the image in 2028 (56r), although the body of the beast in 2028 is more circuitous. The beast located at 13.11 in 2028 (58r) is almost exactly identical to the snake-like land beast in $2044(61 \mathrm{v})$. The mouth of the serpent in 2044 is slightly more open, and the artistic execution of the beast is more skilled in 2028, but these images certainly stand in the same stream of late medieval Greek Apocalypse images associated with the Andreas commentary tradition. The same can be said for the manuscripts' depiction of the whore of Babylon, who in 2044 (80v) enjoys an entire text-less page to herself (cf. Rev 17.13). In 2028 and 2044, the heads of the beast are on the whore's left and she invitingly holds a cup in her right hand, enticing those who behold her. In both cases, the body of the beast is curled. The same cycle of images is also present $2054(174 \mathrm{r}, 180 \mathrm{r}, 189 \mathrm{v}, 202 \mathrm{r})$ and $2083(182 \mathrm{v}, 188 \mathrm{r}, 190 \mathrm{r}, 208 \mathrm{r})$, responding to the same texts $(12.3 ; 13.1-3,11 ; 17.1-3)$. Although this grouping of manuscripts does not follow 2028 in its occasional artistic stylization of capital letters, they share a common tradition as it relates to this cycle of images of Revelation's cosmic antagonists. 2028 is perhaps not the direct textual Vorlage of these manuscripts, but they do share in common a tradition of illustration. ${ }^{34}$

Interestingly, it is difficult also to identify art-historical antecedents for this short cycle of images in these manuscripts, either in the Byzantine ${ }^{35}$ or illuminated Latin traditions (e.g. the Trier, Bamberg, Beatus, Getty, and Douce Apocalypses). ${ }^{36}$ Many of these illuminated Latin manuscripts share a cycle of artistic

34 Schmid, Studien, 1.15: "Diese drei Hss [2044 2054 2083] gehen auf die gleiche Vorlage zurück, wie durch einige gemeinsame Fehler bewiesen wird. Andreas Darmarios hat sie offenbar unmittelbar nacheinander im Jahre 1560 aus einer älteren Hs abgeschrieben. Diese läßt sich aber nicht mehr auffinden, da weder 2028 noch die zwei sogleich zu nennenden venetianischen Hss als Vorlage in Betracht kommen." However, my own initial evaluation shows that the texts of these four manuscripts are closely related in text-genetic terms.

35 See K. Wessel, Buchillustration, in: K. Wessel (ed.), Reallexikon zur Byzantinischen Kunst, vol. 1, Stuttgart 1966, 765-766 who argues that images associated with Revelation only arrive relatively late in the Byzantine tradition of book illustration due to issues of canon. He points only to 2028 and 2044 as examples of this tradition. The Elizabeth Day McMormick Apocalypse (Chicago MS 931), a seventeenth century vernacular Greek manuscript, is richly illuminated, but its depiction of cosmic antagonists differs from the representation in the four Byzantine manuscripts noted above. The artistic traditions in the McCormick Apocalypse owe much to Germanic traditions. For more on this manuscript see H. R. Willoughby and E. C. Colwell (eds.), The Elizabeth Day McMormick Apocalypse, 2 vols., Chicago 1940.

36 Cf. David Ganz, Medien der Offenbarung: Visionsdarstellung im Mittelalter, Berlin 2008, $52-$ 100; Monika E. Müller, Die Johannesapokalypse in der Buchmalerei des 9.-13. Jahrhunderts - Illustrationsprinzipien im Spiegel von Bildtradition und Geistesgeschichte, in: M. Sigismund/M. Karrer/ U. Schmid (eds.), Studien zum Text der Apokalypse (ANTF 47), Berlin 2015, 443-473. See also Peter K. Klein, Introduction: The Apocalypse in Medieval Art, in: R. K. Emmerson/B. McGinn (eds.), The Apocalypse in the Middle Ages, London 1992, 159-199, 
representation that may have antecedents in the fourth century. ${ }^{37}$ Additionally, the Greek tradition of the Apocalypse is bereft of a cycle of images, with only a few isolated examples available. As an example, in the Douce Apocalypse (Bod. MS Douce 180; thirteenth century) the depiction of the dragon differs from 2028 in important ways.

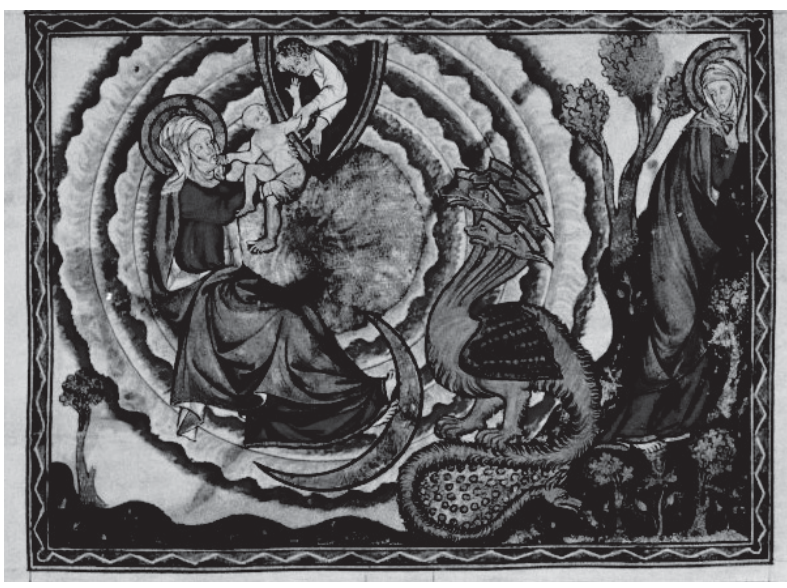

Bod. MS Douce $180(043)^{38}$

First, the image more fully incorporates material from Rev 12.3-6, including depictions of the heavenly woman, her son, and his angelic rescue to heaven. The dragon is but a single actor on a larger canvas. Moreover, the dragons are visualised differently. In Douce, it has feet, wings, and a tail with an additional head. Its horns are not as prevalent and its action of sweeping stars from the sky

esp. 175-199 for a selective overview of the book of Revelation in the visual art of the Middle Ages with a focus on the various cycles images in Apocalypse illuminations. On the Getty Apocalypse in particular see N. J. Morgan, Illuminating the End of Time: The Getty Apocalypse Manuscript, Los Angeles 2011 and on the Spanish Beatus tradition see John Williams, The Illustrated Beatus: A Corpus of Illustrations of the Commentary on the Apocalypse, 5 vols., London 1994-2003.

37 So James Snyder, The Reconstruction of an Early Christian Cycle of Illustrations for the Book of Revelation - The Trier Apocalypse, VC 18 (1964), 146-162.

38 Excerpt from http://bodley30.bodley.ox.ac.uk:8180/luna/servlet/detail/ODLodl 1 1 40066 109116:Apocalypse-with-commentary--known-a?qvq=w4s:/what/MS.\%20Douce\%20180; lc:ODLodl 29 29, ODLodl 7 7, ODLodl 6 6, ODLodl 14 14, ODLodl 8 8, ODLodl $\sim 23 \sim 23$, ODLodl 1 1, ODLodl 24 24\&mi=49\&trs=119 (accessed 17 February 2016). 
is not emphasised as in $2028 .^{39}$ It is difficult to locate a direct connection between the artistic representation in Douce and $2028 .^{40}$ The only exception to this rule might be located in Douce's depiction of the whore of Babylon.

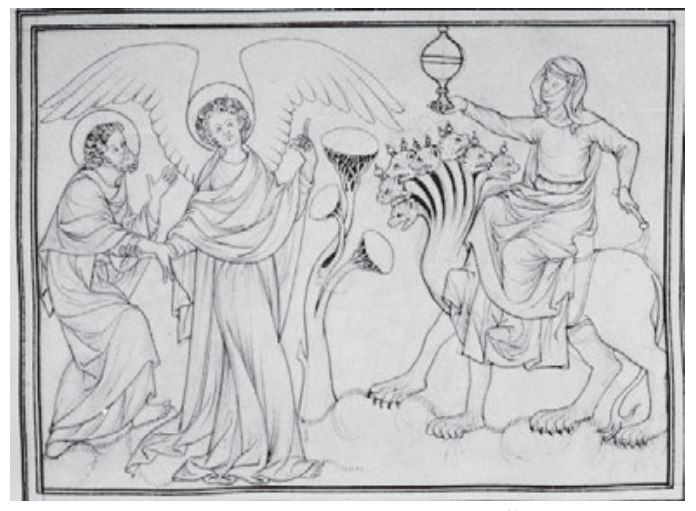

Bod. MS Douce $180(071)^{41}$

Although significant differences between the depictions persist, represented by the dress of the whore, the direction of her beast, the type of beasts (four legs vs. serpent), and the expanded image of the angelic messenger and seer in Douce, striking similarities exist between images. Notably, the whore, riding sidesaddle, holds a chalice in her right hand. The similarities indicate that the images in 2028 share some traditional features of the whore's visualisation, but the precise source remains unclear. ${ }^{42}$

39 This feature of the dragon's action is emphasized in Albrecht Dürer's 1498 elaborate wood carving of Rev 12.1-5. See Paul Huber, Apokalypse: Bilderzyklen zur Johannes-Offenbarung in Trier, auf dem Athos und von Caillaud d'Angers, Düsseldorf 1989, 57.

40 The same is true also for the Bamberg Apocalypse (eleventh century; Bamberger Staatsbibliothek Msc.Bibl.140; cf. J. Maas (ed.), Bamberger Apokalypse, Katalog der Diapositive, ca. 1955, 23 which portrays the dragon among the broader scene of Revelation 12. The dragon here is more serpentine, but takes a menacing stance toward the child, an attitude that is entirely lacking in 2028, owing to the dragon's isolation. See Hans Urs von Balthasar, Die Bilder der Bamberger Apokalypse, Stuttgart 1980.

41 Excerpt from http://bodley30.bodley.ox.ac.uk:8180/luna/servlet/detail/ODLodl 1 1 40103 109105:Apocalypse-with-commentary--known-?qvq=w4s:/what/MS.\%20Douce\%20180; lc: ODLodl $\sim 29 \sim 29$, ODLodl 7 7, ODLodl $\sim 6 \sim 6$, ODLodl $\sim 14 \sim 14$, ODLodl $\sim 8 \sim 8$, ODLodl $\sim 23 \sim 23$, ODLodl 1 1, ODLodl $24 \sim 24 \&$ mi=86\&trs=119 (accessed 17 February 2016).

42 The portrayal of the whore in the Bamberg Apocalypse (von Balthasar, Bilder, 84-85) is also follows this traditional pattern, although she holds her cup in the left hand. Dürer's late-fifteenth century carving (Huber, Apokalypse, 73) shows similarities with the depiction of the whore in 2028. Moreover, the whore is also portrayed similarly in later fifteenth to seventeenth 


\section{Function of the Images}

The role of these images in the reading process differs from the richly illuminated Latin manuscripts mentioned above, which usually contain fifty to eighty images. ${ }^{43}$ In the reading context of the late Middle Ages in a Latin setting, most patrons relied on advisors to "read" the text, allowing the images to act as the primary guide to the work. ${ }^{44}$ However, the paucity of extensive images in 2028, in comparison, allows the text to function as the primary medium of understanding. The encoding of images as Greek letters associated with fifteen of the Andrew kephalaia emphasises the lemmatic text of the commentary manuscriptimages in 2028 are not designed to supersede the text, but to highlight, ornament, and supplement its meaning. ${ }^{45}$

The cycle of antagonistic cosmic players, however, serves other purposes. The first function of these images is mnemonic. They help to situate the reader within the complex narrative texture of judgment and cosmic conflict that works itself out in Revelation 12-22, providing a visual map of the four related antagonists. The visualization of these four images also serves an implicit exegetical function, highlighting not only the importance of the creatures and their menacing nature, but also their interconnectedness. Their shared serpentine features and coiled backsides emphasise their kinship, indicating that they collectively represent a unified hostile force. Moreover, the dragon from Revelation 12 is almost identical to the beast upon which the whore rides in Revelation 17. The dragon, explicitly identified as "the great serpent of old, the one called devil and Satan, the one who leads the whole earth astray" (12.9), is depicted as the cohort of the whore, emphasising her aggressive stance toward God's faithful people, the hearers of the Apocalypse. This small cycle of images "helps us to appreciate their interrelationships with an immediacy that a verbal narrative is bound to lack," or which is only implicit. ${ }^{46}$

The images in 2028, both the stylized Greek letters and the cycle of antagonists, function in multifaceted ways, serving both aesthetic and exegetical functions, interpreting the meaning of Revelation's cosmic enemies, and drawing

century visualizations (e.g. Lucas Cranach's 1522 depiction [BL C.36.g.7]) indicating that 2028 stands within a broader stream of tradition (idem, 206-209).

43 Klein, Introduction, 175.

44 See Natasha F. H. O'Hear, Contrasting Images of the Book of Revelation in Late Medieval and Early Modern Art: A Case Study in Visual Exegesis (OTM), Oxford 2011, 1-22, 207-210.

45 This function of the images in 2028 stands in stark contrast to the role of images in some late medieval and early modern visualizations of the Apocalypse that tend to prioritize the image as a replacement for the (usually Latin) text. Cf. the Anglo-Norman illuminated Apocalypse (e.g. Lambeth Apocalypse) and the Angers tapestry (O'Hear, Contrasting Images, 207-210).

46 Cf. Natasha O'Hear and Anthony O'Hear, Picturing the Apocalypse: The Book of Revelation in the Arts over Two Millennia, Oxford 2015, 4. 
attention to intertextual connections embedded within the text. In this way, the images are the result of text immanent reflection within the context of a broader tradition of artistic visualisation. The producers of this manuscript, at least as far as its artist is concerned, were informed readers and not simply dispassionate craftsmen.

\section{Conclusions}

The illustrations in 2028 offer an additional opportunity to evaluate the reception history of the Apocalypse. First, the stylized kappa in 19.11 constitutes an allusion to an allusion, directing the reader's memory to Ezekiel 1. Whether or not this artistic tradition is original to 2028, it is clear that Byzantine period readers understood that the text of Rev 19.11 and Ezekiel were related in some way. How precisely they interact is not clear, but the image borrowed from Ezekiel's description of angelic beings strongly indicates a connection. Also, the location of the hare being devoured by birds is curious insofar as it might be understood as a visual representation of the Whore of Babylon and her defeat. Second, the cycle of additional serpentine images in 2028 are indicative of scriptural reception. The depictions are crafted in such a way that they draw an implicit connection between beasts, a connection that is surely already implied in the text. Nonetheless, the presence of these images, and only these images, explicates the potential for coordination of the beasts that antagonize God's people. Interestingly, few features of the images are traceable to Andrew's commentary, beyond the observation that the dragon and sea beast are related because they have the same number of heads and horns. The images likely developed independently of the explicit interpretations preserved in the Andreas commentary tradition, suggesting that they are the products of a particular strategy for reading the scriptural text. ${ }^{47}$

The text of the manuscript remains the primary arbiter of tradition. However, other material features offer insight into how the text was comprehended in this period. I have examined only the artistic features of this manuscript here as a channel of tradition, but taking a closer look at other features would also help to fill out the picture of what 2028 has to offer beyond its text. This close look at a particular feature of a particular historically situated manuscript helps us to better understand the function and interpretation of the Apocalypse in this period. To this end, there is much work to be done on Revelation's material culture.

47 These images are rather bare in comparison to other "luxury books" in the Byzantine period, perhaps indicating their social location since Revelation was not part of the Greek liturgical cycle. Cf. J. Lowden, Luxury and Liturgy: The Function of Books, Church and People in Byzantium (1990), 263-280. 


\section{Literature}

G.K. Beale, The Book of Revelation (NIGTC), Grand Rapids 1999.

H. Bordier, Description des peintures et autres ornements contenus dans les manuscrits grecs de la Bibliothèque Nationale, Paris 1883.

K. Busby, Text and Image in the Getty Tristan, Los Angeles, J. Paul Getty Museum, MS Ludwig, 5, in: H. A. Kelly (ed.), Medieval Manuscripts, Their Makers and Users, Los Angeles, 2011, 1-25.

E. S. Constantinou, Andrew of Caesarea: Commentary on the Apocalypse (The Fathers of the Church 123), Washington, D.C. 2011.

B. D. Ehrman, The Orthodox Corruption of Scripture: The Effect of Early Christological Controversies on the Text of the New Testament, Oxford 1993.

J.K. Elliott, New Testament Textual Criticism: The Application of Thoroughgoing Principles: Essays on Manuscripts and Textual Variation (NTSup 137), Leiden 2010.

D. Ganz, Medien der Offenbarung: Visionsdarstellung im Mittelalter, Berlin 2008.

V. Gardthausen, Die Schrift, Unterschriften und Chronologie im Altertum und im byzantinischen Mittelalter, vol. 2, Leipzig 1913.

J. Hernández Jr., Scribal Tendencies in the Apocalypse: Starting the Conversation, in: C. A. Evans/H. D. Zacharias (eds.), Jewish and Christian Scripture as Artifact and Canon (LSTS 70), London 2009, 248-260.

- Scribal Habits and Theological Influences in the Apocalypse (WUNT 2/218), Tübingen 2006.

H.C. Hoskier, Concerning the Text of the Apocalypse, 2 vols., London 1929.

P. Huber, Apokalypse: Bilderzyklen zur Johannes-Offenbarung in Trier, auf dem Athos und von Caillaud d'Angers, Düsseldorf 1989.

H. Hunger, Schreiben and Lesen in Byzanz. Die byzantinische Buchkultur, München 1989.

M. Karrer, Der Text der Johannesapokalypse, in: J. Frey/J.A. Kelhoffer/F. Tóth (eds.), Die Johannesapokalypse: Kontexte - Konzepte - Rezeption (WUNT 287) Tübingen 2012, 43-78.

P.K. Klein, Introduction: The Apocalypse in Medieval Art, in: R. K. Emmerson/B. McGinn (eds.), The Apocalypse in the Middle Ages, London 1992, 159-199.

B. Kowalski, Die Rezeption des Propheten Ezechiel in der Offenbarung des Johannes (SBB 52), Stuttgart 2004. 
M. Lembke, Beobachtungen zu den Handschriften der Apokalypse des Johannes, in: M. Karrer/M. Labahn (eds.), Die Johannesoffenbarung. Ihr Text und ihre Auslegung (ABG 38), Leipzig 2012, 19-69.

J. Lowden, Luxury and Liturgy: The Function of Books, Church and People in Byzantium (1990), 263-280.

J. Maas (ed.), Bamberger Apokalypse, Katalog der Diapositive, ca. 1955.

K. Maxwell, The Afterlife of Texts: Decorative Style Manuscripts and New Testament Textual Criticism, in: L. Jones (ed.), Byzantine Images and their Afterlives: Essays in Honor of Annemarie Weyl Carr, Farnham, 2014, 11-38.

J.T. McQuillen, Fifteenth-Century Book Networks: Scribes, Illuminators, Binders, and the Introduction of Print, PBSA 104 no 4 (2013), 495-515.

N.J. Morgan, Illuminating the End of Time: The Getty Apocalypse Manuscript, Los Angeles 2011.

M.E. Müller, Die Johannesapokalypse in der Buchmalerei des 9.-13. Jahrhunderts - Illustrationsprinzipien im Spiegel von Bildtradition und Geistesgeschichte, in: M. Sigismund/M. Karrer/U. Schmid (eds.), Studien zum Text der Apokalypse (ANTF 47), Berlin 2015, 443-473.

T. Nicklas, The Early Text of Revelation, in: C.E. Hill/M.J. Krueger (eds.), The Early Text of the New Testament, Oxford 2012, 225-238.

J. Noret, Pour une edition de l'Évangelie de l'Enface selon Thomas, Analecta Bollandiana 90 (1972), 412.

N.F.H. O'Hear, Contrasting Images of the Book of Revelation in Late Medieval and Early Modern Art: A Case Study in Visual Exegesis (OTM), Oxford 2011.

N.F.H. O'Hear/A. O'Hear, Picturing the Apocalypse: The Book of Revelation in the Arts over Two Millennia, Oxford 2015.

S.M. Pelekanidis et al. (eds.), The Treasures of Mount Athos: Illuminated Manuscripts, 2 vols., Athens 1974.

P. Prigent, L'Apocalypse de Saint Jean, rev. ed., Geneva 2000.

J.R. Royse, Scribal Habits in Early Greek New Testament Papyri (NTTSD 36), Leiden 2008.

J. Schmid, Studien zur Geschichte des griechischen Apokalypse-Textes (MThS.HE 1), 3 vols., München 1955-1956.

J. Snyder, The Reconstruction of an Early Christian Cycle of Illustrations for the Book of Revelation - The Trier Apocalypse, VC 18 (1964), 146-162.

I. Spatharakis, Corpus of Dated Illuminated Greek Manuscripts to the Year 1453, vol. 1, Leiden 1981. 
R.H. van der Bergh, 'Old Testament Awareness' and the Textual Tradition of the Explicit Quotations of Isaiah in Codex Bezae's Acts, NT 57 (2015), 360-378.

H. Urs von Balthasar, Die Bilder der Bamberger Apokalypse, Stuttgart 1980.

K. Wessel, Buchillustration, in: K. Wessel (ed.), Reallexikon zur Byzantinischen Kunst, vol. 1, Stuttgart 1966, 757-784.

J. Williams, The Illustrated Beatus: A Corpus of Illustrations of the Commentary on the Apocalypse, 5 vols., London 1994-2003.

H.R. Willoughby/E.C. Colwell (eds.), The Elizabeth Day McMormick Apocalypse, 2 vols., Chicago 1940. 